\title{
Looking for the traces of Polish heritage on the map of Ukraine. Linguistic educational game
}

\author{
Śladami polskiego dziedzictwa na mapie Ukrainy. \\ Jęykowa gra edukacyjna
}

\author{
Błogosław dobrym niebom, jeżeli ich wola \\ Dała ci żyć pod słodkim powietrzem Podola; \\ Jakie miłe życie! \\ Czego dusza zapragnie, płynie tu obficie. \\ $(\ldots)$ \\ Jakie dzisiaj Podole, takie było zawsze, \\ Jemu słońce chętniejsze i niebo łaskawsze (Gosławski 2005: 27, 55).
}

Podolia has been long perceived by the Poles as a rich, fertile land flowing with milk and honey, as well as a good training ground for knights where frequent skirmishes with hordes of foreign tribes forged the true spirit of the nation (Osadczy 2007: 5)

That myth of Podolia as a land of plenty had been already shaped in Old Polish literature, as proved by numerous chronicles, from Jan Długosz's Annals onwards It was also significantly influenced by poets in their works revealing anti-Turkish sentiment, determined by political events: constant pressure of Tartar forces and armed conflicts with the Turks (Ryba 2015: 159).

Paintings created by eulogists of Podolian land, the so-called 'Podolian Group,' further contributed to its mythologization. According to Barbara Glikanów-Jadczak, the said group included Maurycy Gosłowski, Tymon Zaborowski, Franciszek Kowalski 
and Stanisław Doliwa Starzyński (Czwórnóg-Jadczak 1996: 639). Undoubtedly, the nostalgic legend of Podolia was fostered and kept alive by Henryk Sienkiewicz and his Trilogy, in particular Fire in the Steppe, where he described the heroic battle for the castle in Kamianets-Podilsky.

The Polish heritage in Podolia is also the main subject of an educational project proposed as part of the "Promotion of Polish Language" programme organized by the Polish National Agency for Academic Exchange (NAWA). The programme is aimed at "promotion of Polish language in connection with elements of Polish history and culture by way of financing undertakings that are supposed to enhance the quality of teaching and the prestige of Polish as foreign language, as well as to have a permanent impact on the image of Poland in the world" (https://nawa.gov.pl/jezyk-polski/ promocja-jezyka-polskiego). The competition is addressed to Polish higher education institutions, but it also promotes projects carried out by international partnerships. Thus, in cooperation with the Faculty of Philosophy and History, University of Lodz, we have submitted a project application titled Polish Heritage on the Map of Ukraine. Creation of an Educational Game and Development of Teaching Materials for Two Levels of Linguistic Proficiency (A1+, B1+) for Ukrainian-Speaking Students of Polish as Foreign Language. The idea was conceived during my work at the Kamianets-Podilsky Ivan Ohienko National University that offers courses of Polish as foreign language. As a teacher of Polish, I asked myself the following questions: How to make the knowledge of 'little homeland,' i.e. history and cultural heritage of Polish nation, attractive to students, while at the same time encourage them to learn Polish? How to make the very process of linguistic education more attractive through activating games and competitions? Howard Gardner, the creator of theory of multiple intelligences (Gardner 2002), believes that the healthiest method of teaching students how to find their inner motivation should be based on the so-called 'flow'. The concept refers to an inner state of satisfaction, or even joy, while simultaneously concentrating on the currently performed activity. The method does not require any other incentives, as learning in itself becomes a sheer pleasure. Students are able to achieve such state of 'flow' when they acquire knowledge in an active way, imperceptibly, in a moment of inspiration and curiosity, but without any compulsion to do so. Thus, teachers should strive to foster that creative attitude in their students (Niesporek-Szamburska 2010: 192).

The idea of the game Polish Heritage on the Map of Podolia, created as part of the project, is based on familiarizing the students with three categories: historic figures, events and architectural monuments. The fourth, additional set, would consists of questions concerning the knowledge of Polish. During classes, the students will learn about people, events and architectural monuments associated with Polish history and cultural heritage. The game requires linguistic preparation of texts for individual categories that would constitute separate teaching units. So, as part of the lesson about Ignacy Jan Paderewski (born in Kuryłówka), the students could be 
familiarized with the declination of male first names ending with -i or -y, as well as male and female last names ending with: -ska, -cka, -dzka, -ski, -cki, -dzki. The historic figure of Delfina Potocka (born in Murowane Kuryłowce) could be a starting point for discussion on fashion and physical appearance. When discussing the urban and architectural complex of the Old Town in Kamianets-Podilsky, the teacher could introduce the topic of trade and services (prices, numbers, measures, etc.). The sets should be adapted for the students' level of linguistic proficiency, i.e. lexical materials for level A1+ students should be easier than those for level B1+. Only after familiarizing themselves with all the categories, would students be able to take part in the game. All players start at the same place on the map (the 'start' field). In order to proceed, they throw a die and move on by the number of fields corresponding to the result, providing they answer correctly to a question from the selected category. All places connected with historic figures, events and architecture should be marked on the board, i.e. the historic map of Podolia.

The key objectives of the game include:

- promotion of Polish culture and history;

- enhancing the interest in learning Polish;

- promotion of Polish historic monuments as supranational values;

- sparking interest in the past, especially the history of 'little homeland';

- instilling humanist values, tolerance and respect for other cultures and religions, and civilization achievements of other nations;

- teaching respect for common historical and cultural heritage.

The choice of a map for the board was not a simple task, since the exact localization of Podolia is disputed from both geographical and historical points of view. In general understanding, the borders of Podolia were always fluid, as some lands that had been administratively separated from it many centuries before, such as the whole area of the former, pre-partition Terebovlia District, were still considered a part of it. Under Russian rule at the close of the 18th century, the territory of Podolia was expanded, as in 1796 tsar Paul I annexed eastern areas beyond Letichyv, Bar and Sharhorod, formerly belonging to pre-partition Bratslav Voivodeship, to Podolian Governorate. Podolia is a land whose actual borders not necessarily correspond to the those of the Podolian Voivodeship, nor can it be placed exactly within the borders of the former Podolian Governorate or the area of the so-called Austrian (Galician) and Russian Podolia (Wolski 1994: V-VI). Thus, for the purposes of the game, a map of Podolia drawn up (prior to 1664) by a French cartographer Guillaume Le Vasseur de Beauplan seems to be the most appropriate. There are several reasons to support that choice. The Podolian Voivodeship was then a part of the Crown of the Kingdom of Poland. Those were the times of expansion of existing towns and establishment of new ones, while the bourgeoisie, craftsmen and merchants were growing in wealth and influence - in other words: 'the age of prosperity.' The map includes all of the 


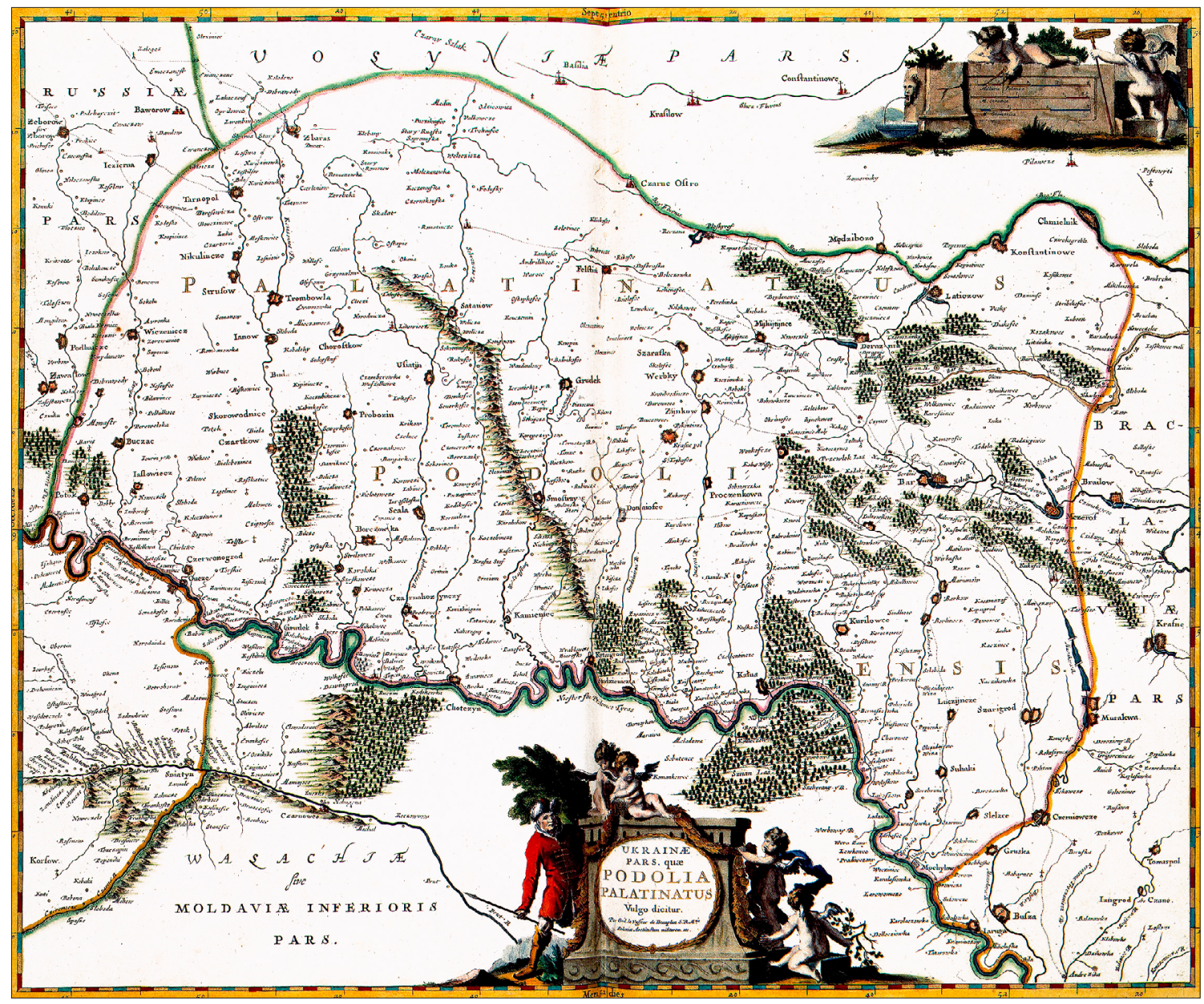

Fig. 1

Map. Podolia proper (Podolian Voivodeship) prior to 1664, Guillaume Le Vasseur de Beauplan

most important towns, is quite legible and the oval shape of borders will facilitate its transformation into a board, as well as the placement of start and finish fields.

The above is one possible version, limiting the game to only one region. The project submitted for the competition concerns a map depicting the whole territory of present-day Ukraine. The game will be also available in digitalized version. The opportunities offered by such map as part of linguistic education are very promising. It proves that the process of teaching Polish does not have be boring - young people can be shown interesting places and familiarized with biographies of prominent historic figures, thus learning about our common cultural heritage. I sincerely believe that linguistic knowledge transferred in this way will be much more attractive than regular classes. 
Despite the fact that computer games are omnipresent in the lives of young people, and despite the increasing number of theoretical works devoted to the possibility of their creative use in education, the issue is still treated by practising teachers as absolutely marginal. And yet, by introducing a computer game as part of a foreign language lesson, a teacher could not only make the classes more attractive, but also increase the students' motivation and develop their specific linguistic skills. Computer games, through active engagement of different senses, stimulate thinking. In addition, the players are given a specific goal to achieve by solving a series of puzzles on their way. As computer games are largely associated with entertainment and leisure activity, their application in glossodidactics meets with highly positive reactions of the students. In the context of teaching foreign language, an especially valuable aspect of the whole experience is the possibility of spontaneous use of language as part of communication between players (Kotuła 2012: 122). This highlights the innovative character of the joint project, as it would be the first ever computer game developed for the purposes of teaching Polish as foreign language (for two levels of linguistic proficiency: A1+ and B1+). Also, nobody before ever used a map for that purpose: to teach respect for the common national heritage. The target group of the game would be not only higher education and high school students of Polish in Ukraine, but also all Ukrainian students in Poland.

\section{Bibliography}

Czwórnóg-Jadczak, B. (1996). Tymon Zaborowski (1799-1828). In: T. Kostkiewiczowa, Z. Goliński (eds), Pisarze polskiego oświecenia, t. 3 (pp. 639-643). Warszawa: Wydawnictwo Naukowe PWN.

Gardner, H. (2002). Inteligencje wielorakie. Teoria w praktyce (transl. A. Jankowski). Poznań: Media Rodzina.

Gosławski, M. (2005). Wybór poezji. Katowice: Wydawnictwo Uniwersytetu Śląskiego.

Kotuła, K. (2012). Gra komputerowa na lekcji języka obcego. Języki Obce w Szkole, 2, 122-124.

Narodowa Agencja Wymiany Akademickiej. Obtainted from: https://nawa.gov.pl/jezyk-polski/promocja-jezyka-polskiego.

Niesporek-Szamburska, B. (2010). Uczyć przez zabawę - od nabywania języka ojczystego do nauki języka obcego (pp. 191-202). In: A. Achtelik, M. Kita, J. Tambor (eds), Sztuka i rzemiosło. Nauczyć Polski i polskiego. Katowice: Wydawnictwo Gnome.

Osadczy, W. (2007). Podole w polskiej historii i kulturze. Teka Komisji Polsko-Ukraińskich Związków Kulturowych, 2, 5-14.

Ryba, R. (2016). Staropolskie żródła romantycznego obrazu Podola (wybrane przykłady). Colloquia Litteraria, 20(1), 159-174. DOI: 10.21697/cl.2016.1.11.

Wolski, K. (1994). „Podole” Oskara Kolberga (pp. V-VI). In: Kolberg, O. Dzieła Wszystkie, t. 47: Podole. Wrocław-Poznań: Polskie Wydawnictwo Ludoznawcze. 


\section{List of figures}

Fig.1. Map. Podolia proper (Podolian Voivodeship) prior to 1664, Guillaume Le Vasseur de Beauplan (source: https://holsta.net/by-artist/boplan-giiom-levasser-de/picture-18261.html)

\section{Summary}

The article describes the idea for an educational game Polskie dziedzictwo na mapie Podola (Polish Heritage on the Map of Podolia) aimed at learning Polish as foreign language using a his torical map. The article presents a map (as a game board) that was drawn up by a 17th-century cartographer Guillaume Le Vasseur de Beauplan. The map of Podolia provides a starting point for preparing scenarios of educational classes that would present historic figures, places, events and architectural monuments connected with Poland. The game is supposed to enhance the interest in learning Polish and teach respect for the common historical and cultural heritage, as well as encourage young people to study the past and discover their 'personal homeland'. The author of the article suggests to use the board game as part of teaching the Polish language. which would certainly make linguistic education more attractive.

Key words: game, map, heritage, teaching and promotion of Polish as foreign language, Podolia

\section{Streszczenie}

Artykuł opisuje koncepcję gry edukacyjnej Polskie dziedzictwo na mapie Podola, której celem jest nauka języka polskiego jako obcego przy wykorzystaniu mapy historycznej. W artykule została zaprezentowana mapa (jako plansza do stworzenia gry), którą sporządził XVII-wieczny kartograf Guillaume Le Vasseur de Beauplan. Mapa Podola staje się punktem wyjścia do napisania scenariuszy zajęć dydaktycznych prezentujących postaci, miejsca, wydarzenia i zabytki architektury związane z Polską. Gra ma na celu wzmacniać zainteresowanie nauką języka polskiego, uczyć szacunku dla wspólnego dziedzictwa historycznego i kulturowego, a także skłonić młodych ludzi do zainteresowania przeszłością i odkrywania "małej ojczyzny”. Autorka artykułu proponuje, aby w proces nauczania języka polskiego włączyć grę planszową, co z pewnością przyczyni się do uatrakcyjnienia kształcenia językowego.

Słowa klucze: gra, mapa, dziedzictwo, nauczanie i promocja języka polskiego jako obcego, Podole 